\title{
Integration of interventional bronchoscopy in the management of lung cancer
}

\author{
Nicolas Guibert ${ }^{1}$, Julien Mazieres ${ }^{1}$, Charles-Hugo Marquette ${ }^{2}$, \\ Damien Rouviere ${ }^{1}$, Alain Didier ${ }^{1}$ and Christophe Hermant ${ }^{1}$
}

\begin{abstract}
Affiliations: 'Service de Pneumologie-Allergologie, Hôpital Larrey - CHU de Toulouse, Université de Toulouse III (Paul Sabatier), Toulouse, France. ${ }^{2}$ Hospital Pasteur and Institute for Research on Cancer and Ageing (IRCAN) (Inserm U10181/UMR CNRS 7284) University Nice Sophia Antipolis, Nice, France.
\end{abstract}

Correspondence: Nicolas Guibert, Unité d'Oncologie Cervico-Thoracique, Service de Pneumologie-Allergologie, Hôpital Larrey, CHU de Toulouse, 24 chemin de Pouvourville, 31059 Toulouse Cedex 9, France.

E-mail: guibert.ndachu-toulouse.fr

ABSTRACT Tracheal or bronchial proximal stenoses occur as complications in $20-30 \%$ of lung cancers, resulting in a dramatic alteration in quality of life and poor prognosis. Bronchoscopic management of these obstructions is based on what are known as "thermal" techniques for intraluminal stenosis and/or placement of tracheal or bronchial prostheses for extrinsic compressions, leading to rapid symptom palliation in the vast majority of patients. This invasive treatment should only be used in cases of symptomatic obstructions and in the presence of viable bronchial tree and downstream parenchyma.

This review aims to clarify 1) the available methods for assessing the characteristics of stenoses before treatment, 2) the various techniques available including their preferred indications, outcomes and complications, and 3) the integration of interventional bronchoscopy in the multidisciplinary management of proximal bronchial cancers and its synergistic effects with the other specific treatments (surgery, radiotherapy or chemotherapy).

0 @ERSpublications

Central airway obstruction is a severe complication of lung cancer that can be managed by interventional bronchoscopy http://ow.ly/OdAhF

\section{Introduction}

The development of interventional bronchoscopy in thoracic oncology is justified, given that $20-30 \%$ of lung cancer cases are complicated by proximal airway obstruction [1], which is responsible for $40 \%$ of deaths [2]. The symptoms related to local extension, such as dyspnoea, atelectasis with post-obstructive pneumonia and haemoptysis, often result in deeply altered quality of life and poor prognosis, with patient survival not exceeding 1-2 months [3-5]. Conventional anti-tumour therapies are of limited value for this type of complication. Surgery, for example, is typically contraindicated for very proximal lesions, chemotherapy has inconsistent and delayed beneficial effects, and radiotherapy is associated with disappointing results, with delayed atelectasis resolution achieved in only $54 \%$ of cases [6]. If the role of interventional bronchoscopy is recognised in thoracic oncology, its use can still be optimised. It appears essential to better determine which technique to use, to set the best time to operate, to anticipate which patients will derive the most benefit, and finally to integrate interventional bronchoscopy within other anti-tumour therapies. We will herein discuss these different points.

\section{Summary and update of available techniques}

Several techniques are currently available for relieving airway obstruction, the choice of which technique to use depends on the stenosis features, the patient's condition, available techniques and the individual

Received: Oct 272014 | Accepted after revision: Dec 022014

Conflict of interest: None declared.

Provenance: Submitted article, peer reviewed.

Copyright OERS 2015. ERR articles are open access and distributed under the terms of the Creative Commons Attribution Non-Commercial Licence 4.0. 
operator's habits $[7,8]$. Mechanical debulking and thermal techniques (laser and thermo-coagulation) are thus reserved for intraluminal tumours [9], while the implementation of tracheal or bronchial prostheses is the preferred management option for extrinsic components [10,11]. Rigid bronchoscopy offers advantages in terms of airway control, the ability to easily remove a large volume of tumour and to deploy silicone stents. The different techniques available are summarised in table 1.

\section{Rigid bronchoscopy and mechanical debulking}

For this procedure, the tracheoscope is introduced under general anaesthesia and visual control, following laryngoscopic visualisation of the vocal cords [9]. Contraindications for rigid bronchoscopy include the presence of cervical spine instability, severe maxillofacial trauma, and obstructive buccal or laryngeal disease $[9,12]$.

In 1989, MATHISEN et al. [13] reported encouraging results after performing solely mechanical debulking on intraluminal tumours with either the bevelled end of different sized calibre rigid tubes or with a large clamp. The procedure was, however, associated with major complications in $20 \%$ of patients, such as pneumothorax, haemoptysis and pneumonia [13]. With the exception of very proximal and low haemorrhage risk tumours, we recommend combining mechanical debulking with a complementary "thermal" technique.

\section{Laser}

Laser therapy is a technique using different gases, such as $\mathrm{CO}_{2}$, and $\mathrm{KTP}, \mathrm{Nd}$ :YAG and diode lasers in order to coagulate or destroy tumours.

In this technique, the laser beam is transferred via a quartz fibre covered with Teflon, aligned with an axis tangential to the wall while preserving a $1 \mathrm{~cm}$-distance from the target zone [14]. This technique enables tumour destruction and haemostasis by means of vessel photocoagulation [4]. Cavaliere et al. [10] proposed an interesting sequence starting with tumour coagulation at $30 \mathrm{~W}$, enabling mechanical debulking, followed by residual tumour tissue destruction at $50 \mathrm{~W}$, then $4-5$-s cycles at $20-30 \mathrm{~W}$ to the implantation base for a prolonged cytotoxic effect $[4,10]$.

Laser therapy targets the intraluminal component of proximal obstructions [9, 12]. Clinical studies have reported constant, immediate and significant improvement in symptoms, quality of life (assessed using the mean \pm SD Karnofsky index which increased from $77 \pm 4$ to $91 \pm 4$ [15]), gas exchange (partial pressure of oxygen from $59 \pm 8 \mathrm{mmHg}$ before intervention; to $78 \pm 6 \mathrm{mmHg}$ after), and ventilatory parameters (improvement of $610 \mathrm{~mL}$ and $428 \mathrm{~mL}$ in forced vital capacity (FVC) and forced expiratory volume in $1 \mathrm{~s}$ (FEV1), respectively) [15-17]. In $92 \%$ of cases $(n=1000)$, the bronchial diameter is restored, especially in cases of proximal tumours (trachea and main bronchi) [18].

The mortality rate directly associated with the laser procedure is low, reported to be $<1 \%(0.8 \%, \mathrm{n}=273$ [15]; $0.7 \%, \mathrm{n}=839$ [19]; $0.67 \%, \mathrm{n}=1000$ [18]; and $0.99 \%, \mathrm{n}=7000$ [7]). Haemorrhages are treated using cold serum, adrenaline or terlipressin local administration, compression with the tube, or short pulses of less than $30 \mathrm{~W}$. Severe haemoptysis only occurs in $1 \%$ of cases $[10,15,19]$. There is a risk of ignition or airway fire, which is usually not serious and can be prevented by maintaining a low inspiratory oxygen fraction $(<0.4)[17,19]$. Potentially fatal complications include tracheobronchial wall perforations causing vascular fistula (very rare cases of massive haemoptysis at powers of $90 \mathrm{~W}$ ) [20], gas embolism, and mediastinitis [19].

In conclusion, laser therapy is extremely effective for alleviating symptoms and rapidly restoring the bronchial lumen, thus, it is particularly indicated in cases of critical proximal exophytic lesions. Complications are rare, provided the procedure is conducted by a trained operator. However, the cost of this technique may be prohibitive in many institutions due to the price of the laser light generator and of the (single use) laser probes.

\section{Thermo-coagulation and argon plasma coagulation}

Thermo-coagulation

Thermo-coagulation, also known as electro-coagulation or electrocautery, involves coagulating or vapourising a tissue by exposing it to heat produced by a high-frequency electric current [7, 9]. High-frequency electric current is delivered to the malignant stenosis, using a monopolar mode, by means of a flexible or rigid probe of varying diameter and form, such as a coagulation electrode, loop [12, 21] or hot biopsy forceps. New-generation generators can be set to different modes [22]. In the "soft coagulation" mode, the heat produced does not exceed $200^{\circ} \mathrm{C}$ and no electric arc is generated, thus preventing tissue from carbonisation and ignition or airway fire, unlike the "forced coagulation" mode. Electrocautery equipment (generator and probes) is far less expensive than laser [22-24]. The symptom improvement observed is constant (96\%) and results in a gain of 53\% in FEV1 [25], equivalent to that obtained with 
TABLE 1 Summary of interventional bronchoscopy techniques available for the management of malignant central airway obstruction

\begin{tabular}{|c|c|c|c|c|c|}
\hline Studies & Anaesthesia & Principle & Indication & Advantages & Drawbacks \\
\hline Mechanical debulking & General & $\begin{array}{l}\text { Resection with the rigid } \\
\text { tubes and forceps }\end{array}$ & $\begin{array}{l}\text { Proximal, slightly } \\
\text { haemorrhagic, and } \\
\text { intraluminal lesions }\end{array}$ & $\begin{array}{l}\text { Rapidity } \\
\text { Cost }\end{array}$ & $\begin{array}{l}\text { Severe complications in } \\
20 \% \text { (bleeding, } \\
\text { perforation) }\end{array}$ \\
\hline Laser & $\begin{array}{l}\text { General anaesthesia and } \\
\text { rigid bronchoscopy highly } \\
\text { recommended, except for } \\
\text { limited degree of stenosis } \\
\text { with short procedure time }\end{array}$ & $\begin{array}{l}\text { Short pulsations in the } \\
\text { bronchial axis at } \\
30-50 \mathrm{~W} \\
\text { Flexible or rigid } \\
\text { bronchoscope }\end{array}$ & $\begin{array}{l}\text { Intraluminal or mixed } \\
\text { critical proximal } \\
\text { obstructions }\end{array}$ & $\begin{array}{l}\text { Immediate and prolonged } \\
\text { debulking } \\
\text { Few complications if } \\
\text { trained operator }\end{array}$ & $\begin{array}{l}\text { Cost } \\
\text { Risk of perforation and } \\
\text { bronchovascular fistula }\end{array}$ \\
\hline $\begin{array}{l}\text { Thermo-coagulation/argon } \\
\text { plasma coagulation (APC) }\end{array}$ & $\begin{array}{l}\text { General anaesthesia and } \\
\text { rigid bronchoscopy highly } \\
\text { recommended, except for } \\
\text { limited degree of stenosis } \\
\text { with short procedure time }\end{array}$ & $\begin{array}{l}\text { High-frequency electric } \\
\text { current } \pm \text { argon as a } \\
\text { carrier gas (APC) }\end{array}$ & $\begin{array}{l}\text { Intraluminal or } \\
\text { mixed proximal } \\
\text { obstructions }\end{array}$ & $\begin{array}{l}\text { Immediate efficacy } \\
\text { Cost } \\
\text { Low risk of perforation } \\
\text { APC: treatment of } \\
\text { extended and } \\
\text { haemorrhagic lesions }\end{array}$ & $\begin{array}{l}\text { Risk of scarring stenosis if } \\
\text { circumferential treatment }\end{array}$ \\
\hline Cryotherapy & $\begin{array}{l}\text { General anaesthesia and } \\
\text { rigid bronchoscopy highly } \\
\text { recommended, except for } \\
\text { limited degree of stenosis } \\
\text { with short procedure time }\end{array}$ & $\begin{array}{l}\text { Expansion of a } \\
\text { cryogenic gas } \\
\text { Cycles of rapid freezing and } \\
\text { slow thawing }\end{array}$ & $\begin{array}{l}\text { Non-critical exophytic } \\
\text { malignant obstructions }\end{array}$ & $\begin{array}{l}\text { Low cost } \\
\text { Easy procedure } \\
\text { No perforation } \\
\text { Prolonged efficacy } \\
\text { Synergistic action with } \\
\quad \text { chemotherapy }\end{array}$ & $\begin{array}{l}\text { Delayed effect lexcept } \\
\text { cryoextraction and spray } \\
\text { cryotherapyl } \\
\text { Need for a second cleaning } \\
\text { bronchoscopy }\end{array}$ \\
\hline Photodynamic therapy & $\begin{array}{l}\text { General anaesthesia and } \\
\text { rigid bronchoscopy highly } \\
\text { recommended, except for } \\
\text { limited degree of stenosis } \\
\text { with short procedure time }\end{array}$ & $\begin{array}{l}\text { Activation of a } \\
\text { photosensitiser by light }\end{array}$ & $\begin{array}{l}\text { Non-critical exophytic } \\
\text { malignant obstructions }\end{array}$ & $\begin{array}{l}\text { Good symptom control } \\
\text { (haemoptysis) } \\
\text { Prolonged efficacy }\end{array}$ & $\begin{array}{l}\text { Delayed effect } \\
\text { Retention of tumour } \\
\quad \text { material } \\
\text { Cleaning bronchoscopy } \\
\text { Phototoxicity } \\
\text { Constraining technique } \\
\text { Haemorrhagic } \\
\text { complications }\end{array}$ \\
\hline Silicone stent & General & $\begin{array}{l}\text { Placed using a prosthesis } \\
\text { pusher inserted in the } \\
\text { rigid tube }\end{array}$ & $\begin{array}{l}\text { Extrinsic or mixed } \\
\text { compressions }\end{array}$ & $\begin{array}{l}\text { Good tolerance } \\
\text { Few local granulomatous } \\
\quad \text { and ischaemic } \\
\text { reactions } \\
\text { Easily removable }\end{array}$ & $\begin{array}{l}\text { Altered ciliary clearance } \\
\text { Risk of migration (rare, } \\
\text { except in cases of purely } \\
\text { extrinsic compression) }\end{array}$ \\
\hline Metallic stent & $\begin{array}{l}\text { General anaesthesia and } \\
\text { rigid bronchoscopy highly } \\
\text { recommended }\end{array}$ & $\begin{array}{l}\text { Self-expandable } \\
\text { Placed using a guide } \\
\text { wire under radiographic } \\
\text { or bronchoscopic control } \\
\text { Flexible or rigid } \\
\text { bronchoscopy }\end{array}$ & $\begin{array}{l}\text { Second line; not to be } \\
\text { considered as a first } \\
\text { choice, except in cases } \\
\text { of highly necrotic } \\
\text { lesions or large } \\
\text { distortion }\end{array}$ & $\begin{array}{l}\text { Easy placement } \\
\text { Possible with flexible } \\
\text { bronchoscope } \\
\text { (but should be } \\
\text { avoided if rigid tube is } \\
\text { unavailable) } \\
\text { Preserved clearance }\end{array}$ & $\begin{array}{l}\text { Frequent complications } \\
\text { (granuloma, perforation, } \\
\text { rupture) } \\
\text { Hardly removable }\end{array}$ \\
\hline
\end{tabular}


laser $[22,25]$. Major complications are rare [26]. The risk of perforation and inflammation is nonexistent in the soft coagulation mode $[5,22,27]$. Circumferentially-applied thermo-coagulation entails a risk of scarring stenosis $[12,28,29]$.

\section{Argon plasma coagulation}

The limitations of thermo-coagulation include restricted access to the most apical segments and loss of efficacy in cases of electric current-induced bleeding [7]. These two drawbacks are overcome by using argon as a carrier gas (non-contact method), a technique requiring an additional probe and generator $[7,9,22,23]$. Argon plasma coagulation is particularly suited for extensive and haemorrhagic lesions. Indeed, as argon (and thus electric current) is transported to the affected vessels through the bloodstream, haemostasis can be achieved even if the origin of bleeding cannot be precisely identified [6, 9, 12, 22, 23]. Argon plasma coagulation is particularly effective for controlling haemoptysis (100\%) [30, 31].

In conclusion, thermo-coagulation is a highly effective technique with the benefits of immediate effect, lower cost and low complication rates. With the exception of bulky exophytic tumours, which are more quickly debulked by laser, thermo-coagulation can be proposed as the first-line treatment. Argon plasma coagulation is an option for managing distal or extended haemorrhagic tumours.

\section{Cryotherapy}

Cryotherapy consists of delivering very low temperatures, obtained by the expansion of a cryogenic liquid gas, to the tissues in order to destroy them $[32,33]$. This process requires a console, a cryoprobe $[34,35]$ and cryogenic gas $\left(\mathrm{N}_{2} \mathrm{O}, \mathrm{N}_{2}, \mathrm{CO}_{2}[9,34]\right)$. The destructive damage inflicted by cryotherapy is both immediate (dehydration and cellular crystallisation) [7, 36-39] and delayed, involving apoptosis and ischaemia (microthrombi formation) [40], leading to a delayed yet prolonged result $[7,36]$.

A large $(2.3 \mathrm{~mm})$ probe (known as a cryo-recanalisation probe) enables more powerful freezing $\left(-89.5^{\circ} \mathrm{C}\right)$ and better retraction, allowing for rapid debulking and immediate repermeabilisation [33]. Spray cryotherapy is a technique that enables low pressure liquid nitrogen $\left(-196^{\circ} \mathrm{C}\right)$ to be administered, producing immediate effects. Like argon plasma coagulation, this technique appears particularly suitable for treating very haemorrhagic and extensive tumours, especially when the origin of the bleeding cannot be precisely identified, as the treatment site is extensive and the haemostatic effect is excellent. Nevertheless, this method still requires validation and does not appear suitable for voluminous tumours, given that the duration of the intervention is long [41].

Cryotherapy is indicated as a palliative treatment of non-obstructive proximal stenoses without acute respiratory distress due to its delayed effects $[9,12]$.

Once again, symptom control is the rule, especially for haemoptysis [32, 35, 42]. With cryo-recanalisation, a normal bronchial calibre can be recovered in $61-91 \%$ of cases [34, 43, 44], allowing for the removal of 57\% and $76 \%$ of total and lobar atelectasis, respectively [32]. A 54.6\% improvement in the Karnofsky performance status index is due to a significant functional benefit, with an improvement in FEV1 and FVC of $65.2 \%$ and $57.8 \%$, respectively [42], and of partial pressure of oxygen (71\% of cases) [32]. This prolonged effect, strengthened by repetitive cryotherapy sessions, is related to an associated cytotoxic effect $[38,39,45]$.

The procedure-related mortality rate is low, reaching $1.2 \%$ [34]. The total complication rate is $<10 \%$ $[34,42]$. The risk of perforation is nonexistent, since the cartilage is extremely cryoresistant $[34,37]$. The most common complication is the retention of tumour material, requiring a bronchial aspiration to be performed 1-2 days later $[31,37,46]$. Cryoextraction and spray cryotherapy are also associated with a low risk of complications $[33,41]$.

In conclusion, cryotherapy is a cost-effective option enabling the sustained control of symptoms when treating symptomatic obstructions without respiratory distress. Cryoextraction is as effective as other thermal methods for treating obstructive stenosis without risk of perforation or residual stenosis and with a low incidence of other complications. Spray cryotherapy still requires validation, yet appears highly promising for the management of haemoptysis related to extensive and hypervascularised lesions.

\section{Stents}

In 1965, Montgomery [40] developed a T-shaped tracheal stent, which required tracheotomy. This stent was further adapted by Dumon [47], who designed a silicone stent by cutting off the horizontal limb of the T-tube. At the same time, self-expandable metallic stents were shown to be of great value, first using endovascular stents (Gianturco) and later on, dedicated airway stents. The ideal prosthesis should: 1) be cost-effective, 2) be easy to place and remove, 3) not migrate, 4) be rigid enough to resist airway compression, yet still flexible enough to mimic airway physiology, 5) not impair mucociliary clearance, and 6) not induce granulomatous reactions [7, 48, 49]. 
Silicone stents

Except in cases of very high tracheal stenoses, contraindicated for surgery, and following dilatation failure [23], the Montgomery T-tube has been replaced by the stent developed by Dumon [47] (Tracheobronxane; Novatech, La Ciotat, France) or its equivalents Polyflexstent (Boston Scientific, Natick, MA, USA), Hood stent (Hood Laboratories, Pembroke, MA, USA) and the Noppen stent (Reynders Medical Supply, Lennik, Belgium). These stents can be straight or bifurcated for stenoses involving the carina [50]. The diameter and size are chosen (and then possibly adjusted by cutting) based not only on three-dimensional scanner data $[36,51,52]$, but crucially on preoperative data (the diameter of the rigid tube exceeding that of the stenosis) $[11,47,53]$. These stents are often recommended as first line treatment $[54,55]$ since they are easy to place and remove, are well tolerated, have a marked vault effect, and cause few granulomatous reactions $[9,47,49]$. Their major drawbacks include the systematic need for general anaesthesia and rigid bronchoscopy, slightly higher migration rate, narrower internal diameter due to wall thickness, and altered mucociliary clearance [7, 49]. The Dynamic Freitag (Rüsch, Kernen, Germany) stent has the unique characteristic of having a flexible posterior wall, thus allowing for a more physiological bronchial calibre during cough and, therefore, for better drainage, as well as enabling a more homogeneous distribution of pressures and a lower risk of granuloma [56, 57].

\section{Self-expandable metallic stents}

The most recent prostheses are self-expandable metallic stents (Ultraflex, Boston Scientific; Alveolus, Charlotte, NC, USA; Aerstent, Leufen, Berlin, Germany), which can be placed under video-bronchoscopic or radioscopic guidance [58]. Their theoretical advantages include the possibility of placement using flexible bronchoscopy, a lower risk of migration, better preserved mucociliary clearance and a larger internal diameter [49]. Except in cases of purely extrinsic compression, covered stents are preferred in neoplastic stenosis, but uncovered stents still have their place in tight and highly distorted stenosis where they maintain a constant diameter even within kinks [54, 59, 60]. Self-expandable coated stents are particularly suitable for covering a fistula, and stop recurrent septic pneumonias [61]. They also offer better waterproofing than silicone stents. The major drawbacks include the risk of granulomatous reactions on the extremities [60], re-epithelialisation of uncovered stents rendering the stent difficult to remove after 3-6 weeks [36], a weaker vault effect [60], and an increased risk of ischaemic mucosal necrosis and, thus, of perforation (with Gianturco stents) [54].

\section{Outcomes in thoracic oncology}

Stent implantation is indicated for the management of the extrinsic component of proximal stenoses and tracheo-oesophageal fistula $[9,49,59]$, or as a supplement to treatment of intraluminal obstructions each time there is some degree of extrinsic component of bronchial wall destruction $[13,15]$. The SPOC (Role of a Silicone Prosthesis to Prevent Airway Obstruction Recurrence After Therapeutic Bronchoscopy in Lung Cancers) French prospective study was the first randomised trial designed to study the benefit of stent implantation after bronchoscopic removal of intraluminal tumours. 75 patients were randomised, of whom 39 received a stent. Stent insertion was proven to be effective in delaying local symptomatic recurrence, but did not improve overall survival [62].

Repermeabilisation is obtained in most cases [63], leading to a significant improvement of dyspnoea [59], haematosis and functional respiratory parameters. For silicone stents, the vast majority of patients feel a benefit in terms of quality of life [10], resulting in improved Karnofsky score (from 36 to 51) [11]. In the case of self-expandable stents, a decrease in Eastern Cooperative Oncology Group (ECOG) score from 3.36 to 2.32 was observed (Ultraflex) [63]. This improvement is objectified by a marked improvement in arterial oxygen saturation measured by pulse oximetry and arterial oxygen tension [48], but also a gain of $340 \mathrm{~mL}$ in FEV 1 and $490 \mathrm{~mL}$ in FVC [59].

\section{Complications}

Silicone stents

The overall complication rate has been reported as 9.4\% $(n=306)$ [10]. Migration risks mainly concern short $(<2.5 \mathrm{~cm})$ and purely extrinsic stenoses $[7,9,60,64]$ and immediate sub-glottic stenoses, and appear relatively rare in cases of obstructions of malignant origin (2-6\% [64] of cases versus $18 \%$ of cases with a benign condition [65]), due to the tumour tissue facilitating stent integration [66]. Granuloma is also rare $(1 \%, n=306[10])$, or at least is symptomatic in only a small number of cases [60]. Other potential complications include haemoptysis [9] and obstruction by secretions (14\% of patients) [23, 55], which are favoured by unavoidable bacterial colonisation [67]. Mucolytic nebulisations and good hydration are needed to avoid such dense secretions. The perforation risk is related to the rigid tube being in contact with highly necrotic lesions, thus indicating the need for a self-expandable stent [68]. 
Self-expandable metallic and hybrid stents

The rate of significant complications is often high for these stents, reaching $16 \%$ in the first month and 13\% after 1 month [69]. Early complications include pneumothorax caused by perforation, pneumonia, and migration [60]. Haemoptysis and infectious complications are seen in $10 \%$ of patients [70]. At later stages, symptomatic granuloma formation is observed in $15-27 \%$ of cases [70, 71].

\section{Conclusion}

The choice between a silicone and self-expandable metallic stent depends on the operator's experience, as well as the stenosis site and mechanism. For silicone stents, complications such as migrations and granulomatous reactions are rare, and these prostheses should be proposed as first line treatment whenever possible. The systematic need for rigid bronchoscopy does not appear a valid argument against the use of these stents, since this access is justified by its capacity for enabling better control of stent placement and related complications, regardless of the type of stent used. Metallic stents are preferentially used in the event of distorted or highly necrotic stenoses and tracheo-oesophageal fistulas.

\section{Other procedures}

Endoscopic dilatation

Endoscopic dilatation consists of inflating (to 3-6 atm pressure) a balloon placed in the centre of an obstructive lesion via radioscopic or video-endoscopic guidance (using a guide wire) $[11,72,73]$. Due to its transient efficacy, this procedure must be considered as the first step of an interventional bronchoscopy, preparing the trachea or the bronchus for stent placement.

\section{Photodynamic therapy}

Photodynamic therapy (PDT) involves destroying a tumour by activating a photosensitising agent (most commonly a haematoporphyrin derivative) using a light source with a specific wavelength $(630 \mathrm{~nm})$, which induces a phototoxic reaction and cell death $[7,9,74,75]$. The drug is eliminated from most tissues within $72 \mathrm{~h}$, yet remains preferentially stored in the skin, liver, spleen and, above all, in the malignant cells [10]. Like cryotherapy, PDT achieves marked, yet delayed, symptom improvement and is, therefore, not suitable for critical proximal obstructions.

A second bronchoscopy must be performed 1-2 days later to remove necrotic tumour tissue and then after 5-7 days to expose residual tissue to a second illumination [40, 74, 76-78]. PDT is particularly effective in controlling haemoptysis (99\%) and dyspnoea, with repermeabilisation and spirometric improvement (a significant improvement of $280 \mathrm{~mL}$ and $430 \mathrm{~mL}$ for FEV1 and FVC, respectively [76]) obtained in the majority of cases $[76,79,80]$.

A phototoxic reaction is observed in $5-28 \%$ of patients and haemoptysis in $18 \%$ (of which $2.2 \%$ have been reported as fatal, $n=636$ ) [74]. Since the collagen remains unaffected, the risk of perforation is nonexistent [81]. The mortality rate is non-negligible, reaching $9 \%$ during the first month [79]. Preventive measures (e.g. sun avoidance for 6 weeks) are effective, despite appearing overly restrictive for a population with limited life expectancy [79].

\section{Brachytherapy}

Brachytherapy involves applying radioactive isotopes (Iridium 192) in a highly localised manner to the tumour in order to preserve neighbouring healthy tissues by using a graduated radio-opaque catheter under video-endoscopic guidance [9]. While symptoms and functional parameters usually improve with this technique, the rate of severe complication is substantial and reported as between 13 and $20 \%[82,83]$. Death from massive haemoptysis has been reported in up to $7 \%$ of patients $(n=342)$ [83]. Radiation bronchitis, which is often fatal and associated with necrosis followed by abscess formation, occurs in $14-35 \%$ of patients [84-86].

Although brachytherapy still constitutes an interesting option for treating radio-occult lesions, or for treating $<3 \mathrm{~cm}$ endobronchial infiltrations for patients with respiratory insufficiency, contralateral recurrence after pneumonectomy or as a complementary technique to incomplete resection surgery [40, $87,88]$, it should not be used as a first-line in the palliative treatment of malignant obstructions.

\section{Microdebrider}

The microdebrider is a tool combining a rotating blade and suction. This technique allows for rapid debulking, as the suction simultaneously evacuates the tumour debris with no risk of perforation, the result being superficial and visible to the naked eye. A good endoscopic outcome is typically achieved in $98 \%$ of cases ( $\mathrm{n}=51$, including 36 nonsmall cell lung cancer cases) $[89,90]$. 


\section{Combination of techniques}

Although some of the techniques appear to compete with one another, for example laser and thermocoagulation $[37,91]$, others can be complementary, for example stent placement following debulking $[28,49$, 91]. The synergistic combination of laser, used for immediate effect, and brachytherapy, used for a lasting effect $[85,92-96]$, has been proven to achieve excellent symptomatic responses and extended survival (laser treatment and brachytherapy versus laser only: $60 \%$ versus 30\% survival at 7 months [97]; median survival 7.5 months versus 2.2 months [86], respectively). However, the severe complications related to brachytherapy are frequent in this context [98], and a study that analysed 378 procedures in 121 patients showed similar outcomes whether or not the laser technique was combined with brachytherapy [99]. This sequence is, therefore, of little interest. The use of cryotherapy on the implantation base of solely intraluminal tumours, associated with a mechanical debulking treatment and/or laser/thermo-coagulation is probably an interesting option for an immediate and quick effect as well as a prolonged cytotoxic effect. For highly haemorrhagic tumours, an artery embolisation preceding the interventional bronchoscopy can be discussed.

\section{Anaesthesia}

The majority of patients exhibit a severely altered general status (ASA 3 or 4) due to cardiac or respiratory comorbidities or to obstructive pneumonia $[7,9,12]$. These cases, therefore, call for an anaesthesiologist who is familiar with the different procedures that may be performed. The various thermal techniques can be performed under sedation using flexible bronchoscopy via a laryngeal mask in cases of small, low haemorrhage risk tumours. Placing a self-expandable prosthesis is possible, but challenging under flexible bronchoscopy. Whichever technique is used, a threatening tracheal obstruction requires rigid bronchoscopy and the use of a short general anaesthetic, usually a combination of propofol and a short half-life opioid [40, 100].

Two ventilation modalities are available. Spontaneous ventilation, alternated with bag-valve-mask ventilation, is associated with a risk of barotrauma. The principle of jet ventilation is to deliver gas at high frequency $\left(100-200 \mathrm{c} \cdot \mathrm{min}^{-1}\right)$, high pressure $(3-5 \mathrm{bar})$ and small volume $\left(2-3 \mathrm{~mL} \cdot \mathrm{kg}^{-1}\right)$. Jet ventilation allows the patient to be ventilated continuously without the risk of barotrauma [101].

\section{Patient selection}

\section{Obstruction characteristics}

The malignant central airway obstructions that require bronchoscopic management are those that affect a proximal airway (trachea and main bronchi), with the identification of a healthy bronchial tree and viable parenchyma beyond the stenosis. In the case of obstruction at the lobar level, bronchoscopic approaches are only indicated for controlling haemoptysis or draining a post-obstructive pneumonia, since ventilation is not significantly improved in these cases [23]. In the case of documented pulmonary artery thrombosis, debulking is associated with a risk of an enhanced dead space effect [4].

Initial flexible bronchoscopy, the benefits of which may be enhanced by using ultra-thin fiberscopes for impassable tumour cases [42] or radial ultrasonography for analysing vascular relationships [102], is the best method for assessing not only stenosis mechanisms and extension, but particularly the permeability of the bronchial tree beyond the stenosis. A chest computed tomography (CT) scan with three-dimensional reconstructions is a valuable tool for determining bronchial tree and parenchyma viability, thereby informing the choice of stent [38]. Spirometric analysis is only indicated in clinical studies, since the expected benefit is symptomatic [103].

\section{Patient characteristics}

This is a key element of bronchoscopic management, with the aim to avoid invasive techniques in patients who will not benefit and select the best patients for whom the benefit will be sustained. In a recent retrospective study, we identified several simple prognostic factors (histology, grade, ASA score and previous treatment) that enabled us to determine subgroups of patients (using the CART (classification and regression trees) segmentation technique) who appear to benefit the most from the treatment. The median life expectancy of these patients is typically very limited, 4.7 months in our study, but with great variability, from 13 months for previously untreated squamous cell carcinomas to less than 1 month for ASA 4 adenocarcinomas [104]. The procedure-related mortality rate is low, however, reaching $1.9 \%$ in our study, which involved only patients with metastatic disease whose general status was extremely altered.

Our retrospective study has reinforced our impression that metastatic patients (relative risk 1.83) with poor general status (anaesthetic score ASA 4, relative risk 2.57) who have chemosensitive tumours but a poor prognosis (relative risk 1.7 for large cell carcinoma and 1.55 for small cell carcinoma) are not ideal candidates. However, our study revealed survival in previously treated patients to be significantly better 
when compared with that of untreated patients (relative risk 0.53), even following adjustment for other prognostic factors. This provides further evidence that interventional bronchoscopy must not be considered as a last chance procedure after having tried all other treatment options. It should instead be included in multimodal management and combined with specific treatments to improve their tolerability (e.g. drainage of a post-obstructive pneumonia before chemotherapy and aplasia episodes, resolving atelectasis so as to re-examine radiation fields).

All these potential prognostic factors must be validated prospectively. This will enable a more precise evaluation of the efficacy of this technique in terms of survival and, above all, quality of life, as well as allowing the identification of patient subgroups that will benefit from a better quality of life and longer survival. A recent prospective study on 947 patients evaluated quality of life (as a secondary end-point) after bronchoscopic treatment of central airway obstruction. Health-related quality of life (SF-6D) was improved in $76(42 \%)$ out of 183 patients measured [105]. In the SPOC trial a dramatic improvement of quality of life (Quality of Life 30 Lung Cancer 13 (QLC 30 LC-13)) was observed in both arms, with a more durable effectiveness in the stent arm [62]. So far, only two small studies have evaluated the effectiveness of a multimodal interventional bronchoscopy on quality of life. AmJADI et al. [106] showed, in 20 patients, an improvement in dyspnoea score, but not in the overall quality of life score measured by the EORTC (European Organisation for Research and Treatment of Cancer) score. The second study, which involved 37 patients, could not establish a significant improvement in the overall score (EORTC LC13) either [107].

\section{Timing of interventional bronchoscopy in the multimodal management of proximal cancer}

Interventional bronchoscopy must be included in multimodal management, which usually consists of chemotherapy, radiotherapy and sometimes surgery. Survival is improved by "adjuvant" treatment with chemotherapy or radiotherapy (38 versus 6 months median survival) $[16,44,98]$. Similarly, survival appears improved when debulking procedures are proposed straight away and not as a last resort (37 versus 10 months median survival) $[17,98]$. Figure 1 summarises the decision process to be undertaken in cases of proximal malignant obstruction and figure 2 suggests a possible decision tree outlining the techniques to be favoured according to the characteristics of the stenosis.

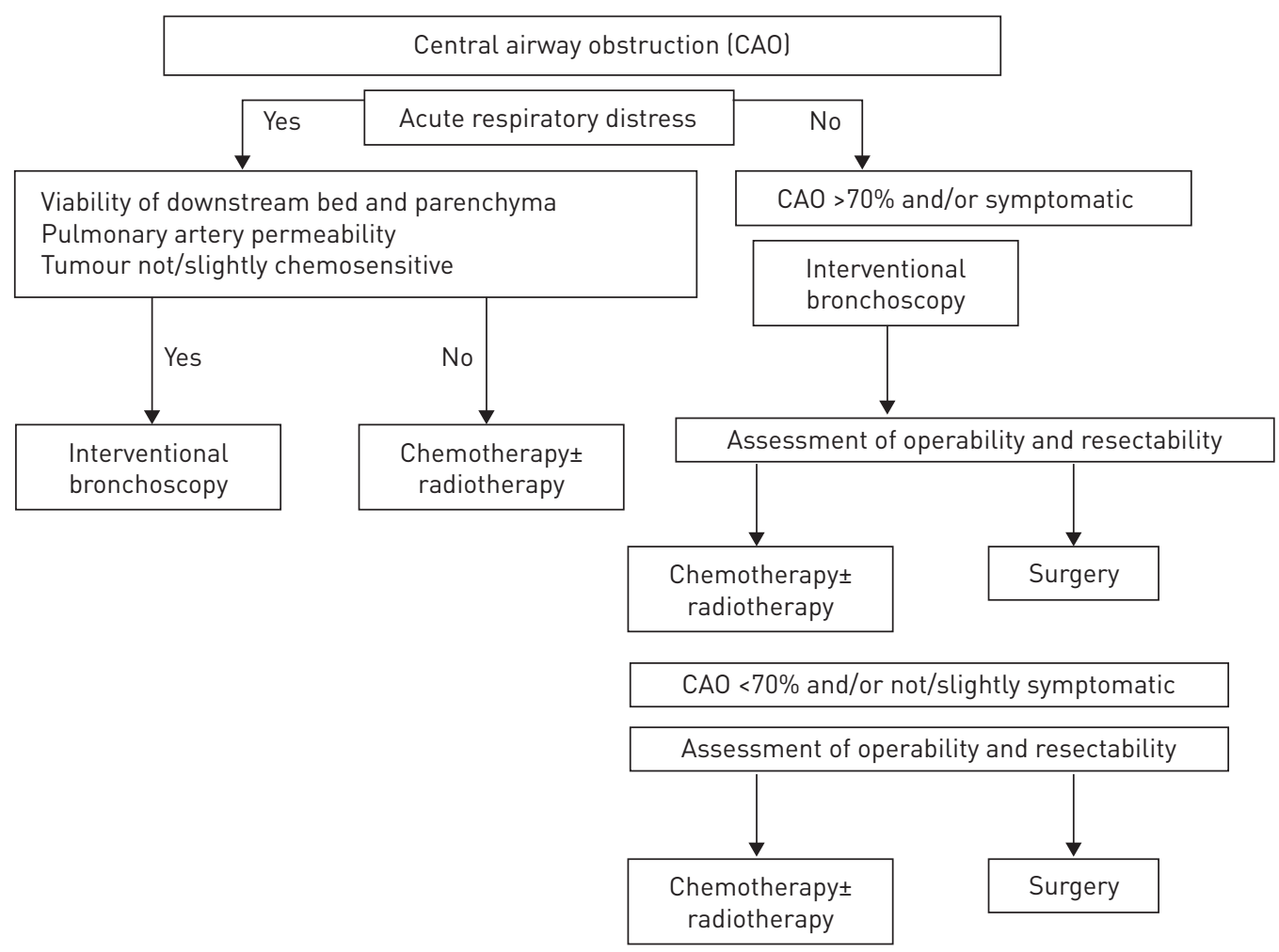

FIGURE 1 Decision process to be undertaken in cases of proximal malignant obstruction. 


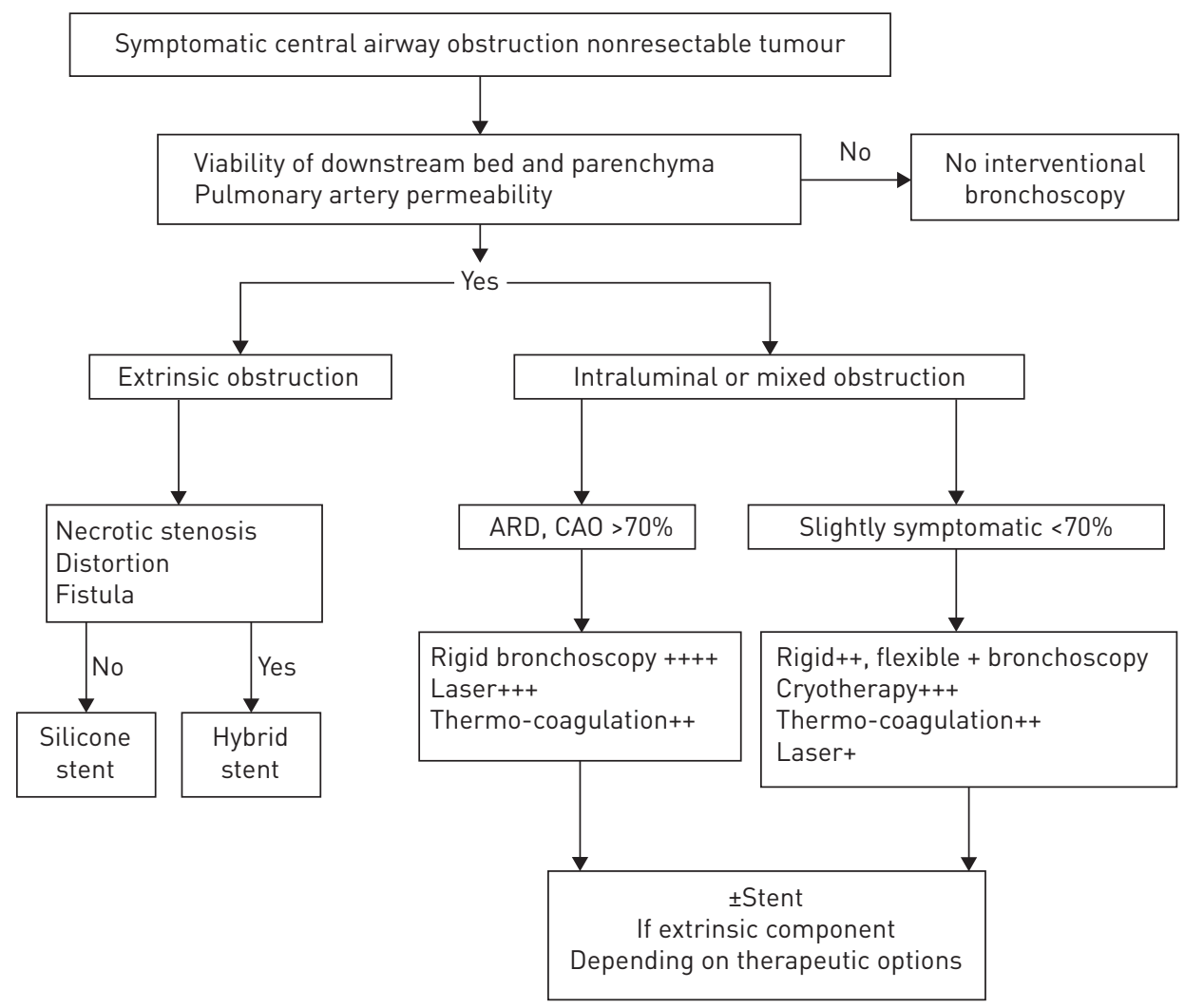

FIGURE 2 Decision tree outlining the techniques to be favoured according to the characteristics of the stenosis. ARD: acute respiratory distress; CAO: central airway obstruction. The number of plus symbols indicates the level of recommendation, from + (probably not to be considered as first line) to ++++ (highly recommended).

\section{Emergency setting}

For cases of new-onset acute respiratory distress, the available data are often scarce. It is, therefore, advisable to seek out, at the very least, histological data and details of the permeability of the downstream bronchial tree and of the pulmonary artery.

When the tumour is highly chemosensitive, such as in cases of small cell carcinoma or lymphoma, and involves infiltration of the distal bronchial tree or a nonviable parenchyma, as seen in lymphangitis and multiple bilateral nodules, this is not a suitable procedure and initiating a specifically-designed treatment seems to be the priority [9].

In all other cases, bronchoscopic management is undisputed and, in the vast majority of cases, enables physicians to "clear a hurdle", as it were, and initiate treatment under the right conditions. For example, implanting a self-expandable prosthesis under flexible bronchoscopy, following respiratory distress complications to a malignant tracheobronchial obstruction, achieves ventilator weaning within $24 \mathrm{~h}$ in over $75 \%$ of cases $[41,56,57,108]$.

\section{Non-emergency setting}

Debulking and surgery

Surgery may sometimes be suggested for treating malignant central stenoses, usually based on pneumonectomy and occasionally extended to the trachea and carina, with reconstruction in cases of proximal involvement [109]. In cases where there has been prior debulking, it is sometimes possible to proceed with more conservative surgery than expected $(61 \%$ of cases, $n=74)$ or even to operate tumours initially thought to be inoperable $[15,18,91,92]$. Tumour size is, in fact, often revised downwards, with nodal status at times being distorted by the presence of post-obstructive pneumonia.

\section{Debulking and radiotherapy}

While radiotherapy has proven highly effective in haemoptysis management, it does only resolve atelectasis in $23-54 \%$ of cases $[6,110]$, and that is only as a delayed outcome (median 24 days). This suggests that some benefit could be gained by prior local treatment [7]. The laser sequence, followed by radiotherapy (fig. 3), offers extended survival (median: 11 months) [111], even if a prior laser procedure increases the risk of haemoptysis 

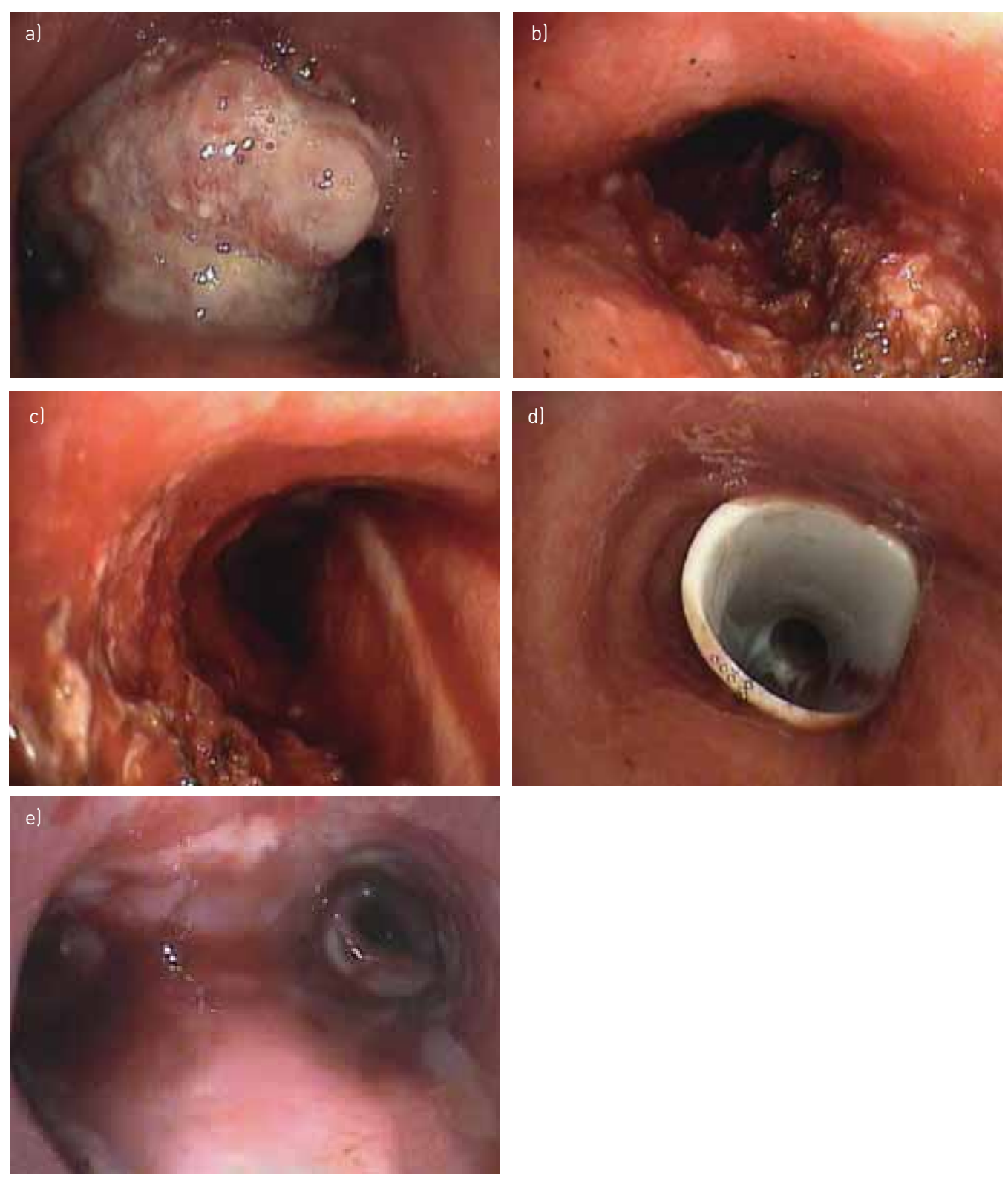

FIGURE 3 Multimodal management of a central airway obstruction by a squamous cell carcinoma using laser and temporary carinal stent placement, followed by radiation therapy. a) Large carinal tumour involving the two main bronchi. Results after laser treatment on the b) left and c) right main bronchi. d) Proximal view of a Y Dumon stent stenting the trachea and the main stem bronchi. e) Result after radiation therapy and stent removal.

[4]. A synergistic effect has been demonstrated with combined cryotherapy and radiotherapy (median survival: 19 months; $65 \%$ histological remission in irradiated patients following cryotherapy considered effective based on endoscopic criteria) $[63,65]$. This synergy has also been suggested for PDT by a randomised study involving a small sample size [112]. The temporary bracing of the airways with a stent is also a useful option for making progress against infection and reducing the volume to be irradiated by resolving the atelectasis prior to radiotherapy $[11,17,113,114]$. Thermo-coagulation has also been found to achieve good outcomes when associated with radiotherapy or brachytherapy [115]. New radiotherapy techniques seem particularly suitable for the management of central airway obstructions and should, where possible, be associated with bronchoscopic treatment. For example, the incorporation of 2-fluoro-2-deoxy-D-glucose positron emission tomography-CT for radiotherapy planning results in better distinction of malignant tissue in cases of collapsed lung [116]. Adaptive radiotherapy allows re-planning of treatment in the presence of significant changes in the patient's tumour position (e.g. lobe re-expansion or variations in the mediastinum position) [117]. Finally, intensity modulated radiotherapy allows patient-specific tight tumour margins and reduced rates of radiation-associated toxicity and seems particularly indicated in tumours that are very near the organ at risk [118]. 


\section{Debulking and chemotherapy}

In addition to improving the patient's general status and management of associated pneumonia, thus improving tolerance to chemotherapy, a synergistic effect has been demonstrated with cryotherapy [63], as cryotreated cells respond more easily to chemotherapy [119].

\section{Conclusion}

Each of the techniques available to interventional bronchoscopists enables the restoration of a patent bronchial lumen and significant improvement of symptoms. Rigid bronchoscopy is recommended in the vast majority of the cases, except for cases with low haemorrhage risk and small lesions. The choice of technique(s) depends on the operator's experience, along with the characteristics of the stenosis and expected time before the treatment takes effect. Mechanical debulking, laser and thermo-coagulation are the preferred options for critical obstructions. Cryotherapy is highly effective in nonrespiratory emergency cases, as its effectiveness is delayed, but prolonged. Implanting a prosthesis can resolve extrinsic obstructions and delay local recurrence of intraluminal components.

Bronchoscopic debulking offers a synergistic action in combination with all other bronchial cancer treatments and should be included in multimodal management as soon as the first symptoms develop, rather than as a last resort. All things considered, the challenge for interventional bronchoscopy is to be part and parcel of the multimodal management of lung cancer for better palliation and quality of life. This is best achieved by identifying the technique or combination of techniques that should be used, setting the best time to operate and anticipating which patients will derive the most benefit.

\section{References}

1 Ginsberg RJ, Vokes EE, Ruben A. Non-small cell lung cancer. In: DeVita VT, Hellman S, Rosenberg SA, eds. Cancer: Principles and Practice of Oncology. 5th Edn. Philadelphia, Lippincott-Raven, 1997; pp. 858-911.

2 Laumanen R, Watson W. Autopsy findings. In: Watson W, ed. Lung Cancer: a Study of Five Thousand Memorial Hospital Cases. St Louis, Mosby, 1968; 504-510.

3 Walser EM, Robinson B, Raza SA, et al. Clinical outcomes with airway stents for proximal versus distal malignant tracheobronchial obstructions. J Vasc Interv Radiol 2004; 15: 471-477.

4 Macha HN, Becker KO, Kemmer HP. Pattern of failure and survival in endobronchial laser resection. A matched pair study. Chest 1994; 105: 1668-1672.

$5 \quad$ Hollingsworth HM. Wheezing and stridor. Clin Chest Med 1987; 8: 231-240.

6 Nihei K, Ishikura S, Kawashima M, et al. Short-course palliative radiotherapy for airway stenosis in non-small cell lung cancer. Int J Clin Oncol 2002; 7: 284-288.

$7 \quad$ Ernst A, Feller-Kopman D, Becker HD, et al. Central airway obstruction. Am J Respir Crit Care Med 2004; 169: $1278-1297$.

8 Freitag L, Ernst A, Unger M, et al. A proposed classification system of central airway stenosis. Eur Respir J 2007; 30: 7-12.

9 Bolliger CT, Mathur PN, Beamis JF, et al. ERS/ATS statement on interventional pulmonology. European Respiratory Society/American Thoracic Society. Eur Respir J 2002; 19: 356-373.

10 Cavaliere S, Venuta F, Foccoli P, et al. Endoscopic treatment of malignant airway obstructions in 2,008 patients. Chest 1996; 110: 1536-1542.

11 Bolliger CT, Probst R, Tschopp K, et al. Silicone stents in the management of inoperable tracheobronchial stenoses. Indications and limitations. Chest 1993; 104: 1653-1659.

12 Ernst A, Silvestri GA, Johnstone D. Interventional pulmonary procedures: guidelines from the American College of Chest Physicians. Chest 2003; 123: 1693-1717.

13 Mathisen DJ, Grillo HC. Endoscopic relief of malignant airway obstruction. Ann Thorac Surg 1989; 48: 469-473.

14 Dumon JF, Reboud E, Garbe L, et al. Treatment of tracheobronchial lesions by laser photoresection. Chest 1982; 81: $278-284$.

15 Venuta F, Rendina EA, De Giacomo T, et al. Nd:YAG laser resection of lung cancer invading the airway as a bridge to surgery and palliative treatment. Ann Thorac Surg 2002; 74: 995-998.

16 Han CC, Prasetyo D, Wright GM. Endobronchial palliation using Nd:YAG laser is associated with improved survival when combined with multimodal adjuvant treatments. J Thorac Oncol 2007; 2: 59-64.

17 Kvale PA, Eichenhorn MS, Radke JR, et al. YAG laser photoresection of lesions obstructing the central airways. Chest 1985; 87: 283-288.

18 Cavaliere S, Foccoli P, Farina PL. Nd:YAG laser bronchoscopy. A five-year experience with 1,396 applications in 1,000 patients. Chest 1988; 94: 15-21.

19 Dumon JF, Shapshay S, Bourcereau J, et al. Principles for safety in application of neodymium-YAG laser in bronchology. Chest 1984; 86: 163-168.

20 Brutinel WM, Cortese DA, McDougall JC, et al. A two-year experience with the neodymium-YAG laser in endobronchial obstruction. Chest 1987; 91: 159-165.

21 van Boxem TJ, Westerga J, Venmans BJ, et al. Tissue effects of bronchoscopic electrocautery: bronchoscopic appearance and histologic changes of bronchial wall after electrocautery. Chest 2000; 117: 887-891.

22 Tremblay A, Marquette CH. Endobronchial electrocautery and argon plasma coagulation: a practical approach. Can Respir J 2004; 11: 305-310.

23 Bolliger CT, Sutedja TG, Strausz J, et al. Therapeutic bronchoscopy with immediate effect: laser, electrocautery, argon plasma coagulation and stents. Eur Respir J 2006; 27: 1258-1271.

24 Boxem TV, Muller M, Venmans B, et al. Nd-YAG laser vs bronchoscopic electrocautery for palliation of symptomatic airway obstruction: a cost-effectiveness study. Chest 1999; 116: 1108-1112. 
Petrou M, Kaplan D, Goldstraw P. Bronchoscopic diathermy resection and stent insertion: a cost effective treatment for tracheobronchial obstruction. Thorax 1993; 48: 1156-1159.

Horinouchi H, Miyazawa T, Takada K, et al. Safety study of endobronchial electrosurgery for tracheobronchial lesions: multicenter prospective study. J Bronchology 2008; 15: 228-232.

Hooper RG, Jackson FN. Endobronchial electrocautery. Chest 1988; 94: 595-598.

Coulter TD, Mehta AC. The heat is on:
photoresection. Chest 2000; 118: 516-521.

Verkindre C, Brichet A, Maurage CA, et al. Morphological changes induced by extensive endobronchial electrocautery. Eur Respir J 1999; 14: 796-799.

Morice RC, Ece T, Ece F, et al. Endobronchial argon plasma coagulation for treatment of hemoptysis and neoplastic airway obstruction. Chest 2001; 119: 781-787.

Okada S, Yamauchi H, Ishimori S, et al. Endoscopic surgery with a flexible bronchoscope and argon plasma coagulation for tracheobronchial tumors. J Thorac Cardiovasc Surg 2001; 121: 180-182.

Marasso A, Gallo E, Massaglia GM, et al. Cryosurgery in bronchoscopic treatment of tracheobronchial stenosis. Indications, limits, personal experience. Chest 1993; 103: 472-474.

Hetzel M, Hetzel J, Schumann C, et al. Cryorecanalization: a new approach for the immediate management of acute airway obstruction. J Thorac Cardiovasc Surg 2004; 127: 1427-1431.

Maiwand MO, Asimakopoulos G. Cryosurgery for lung cancer: clinical results and technical aspects. Technol Cancer Res Treat 2004; 3: 143-150.

Maiwand MO. Cryotherapy for advanced carcinoma of the trachea and bronchi. Br Med J (Clin Res Ed) 1986; 293: 181-182.

Dasgupta A, Dolmatch BL, Abi-Saleh WJ, et al. Self-expandable metallic airway stent insertion employing flexible bronchoscopy: preliminary results. Chest 1998; 114: 106-109.

Vergnon J-M, Huber RM, Moghissi K. Place of cryotherapy, brachytherapy and photodynamic therapy in therapeutic bronchoscopy of lung cancers. Eur Respir J 2006; 28: 200-218.

Asimakopoulos G, Beeson J, Evans J, et al. Cryosurgery for malignant endobronchial tumors: analysis of outcome. Chest 2005; 127: 2007-2014.

Vergnon JM, Schmitt T, Alamartine E, et al. Initial combined cryotherapy and irradiation for unresectable non-small cell lung cancer. Preliminary results. Chest 1992; 102: 1436-1440.

Montgomery WW. T-tube tracheal stent. Arch Otolaryngol 1965; 82: 320-321.

Finley DJ, Dycoco J, Sarkar S, et al. Airway spray cryotherapy: initial outcomes from a multiinstitutional registry. Ann Thorac Surg 2012; 94: 199-203.

Maiwand MO. The role of cryosurgery in palliation of tracheo-bronchial carcinoma. Eur J Cardiothorac Surg 1999; 15: 764-768.

Schumann C, Hetzel M, Babiak AJ, et al. Endobronchial tumor debulking with a flexible cryoprobe for immediate treatment of malignant stenosis. J Thorac Cardiovasc Surg 2010; 139: 997-1000.

Walsh DA, Maiwand MO, Nath AR, et al. Bronchoscopic cryotherapy for advanced bronchial carcinoma. Thorax 1990; 45: 509-513.

Homasson JP, Renault P, Angebault M, et al. Bronchoscopic cryotherapy for airway strictures caused by tumors. Chest 1986; 90: 159-164.

Hauck RW, Lembeck RM, Emslander HP, et al. Implantation of Accuflex and Strecker stents in malignant bronchial stenoses by flexible bronchoscopy. Chest 1997; 112: 134-144.

Dumon JF. A dedicated tracheobronchial stent. Chest 1990; 97: 328-332.

Mroz RM, Kordecki K, Kozlowski MD, et al. Severe respiratory distress caused by central airway obstruction treated with self-expandable metallic stents. J Physiol Pharmacol 2008; 59: Suppl. 6, 491-497.

Chin CS, Litle V, Yun J, et al. Airway stents. Ann Thorac Surg 2008; 85: S792-S796.

Dutau H, Toutblanc B, Lamb C, et al. Use of the Dumon Y-stent in the management of malignant disease involving the carina: a retrospective review of 86 patients. Chest 2004; 126: 951-958.

Lee KS, Boiselle PM. Update on multidetector computed tomography imaging of the airways. J Thorac Imaging 2010; 25: 112-124.

Boiselle PM, Ernst A. Recent advances in central airway imaging. Chest 2002; 121: 1651-1660.

Oki M, Saka H. Thin bronchoscope for evaluating stenotic airways during stenting procedures. Respiration 2011; 82: 509-514.

Puma F, Farabi R, Urbani M, et al. Long-term safety and tolerance of silicone and self-expandable airway stents: an experimental study. Ann Thorac Surg 2000; 69: 1030-1034.

Saji H, Furukawa K, Tsutsui H, et al. Outcomes of airway stenting for advanced lung cancer with central airway obstruction. Interact Cardiovasc Thorac Surg 2010; 11: 425-428.

Freitag L, Eicker R, Linz B, et al. Theoretical and experimental basis for the development of a dynamic airway stent. Eur Respir J 1994; 7: 2038-2045.

Freitag L, Tekolf E, Stamatis G, et al. Clinical evaluation of a new bifurcated dynamic airway stent: a 5-year experience with 135 patients. Thorac Cardiovasc Surg 1997; 45: 6-12.

Du Rand IA, Barber PV, Goldring J, et al. British Thoracic Society guideline for advanced diagnostic and therapeutic flexible bronchoscopy in adults. Thorax 2011; 66: Suppl. 3, iiil-iii21.

Miyazawa T, Yamakido M, Ikeda S,
stenoses. Chest 2000; 118: 959-965.

Husain SA, Finch D, Ahmed M, et al. Long-term follow-up of ultraflex metallic stents in benign and malignant central airway obstruction. Ann Thorac Surg 2007; 83: 1251-1256.

Hürtgen M, Herber SCA. Treatment of malignant tracheoesophageal fistula. Thorac Surg Clin 2014; 24: 117-127. Vergnon JM, Thibout $\mathrm{Y}$, Dutau $\mathrm{H}$, et al. Is a stent required after the initial resection of an obstructive lung cancer? The lessons of the SPOC trial, the first randomized study in interventional bronchoscopy. Eur Respir J 2013; 42: Suppl. 57, P3752.

Razi SS, Lebovics RS, Schwartz G, et al. Timely airway stenting improves survival in patients with malignant central airway obstruction. Ann Thorac Surg 2010; 90: 1088-1093. 
Neyman K, Sundset A, Espinoza A, et al. Survival and complications after interventional bronchoscopy in malignant central airway obstruction: a single-center experience. J Bronchology Interv Pulmonol 2011; 18: 233-238. Martinez-Ballarin JI, Diaz-Jimenez JP, Castro MJ, et al. Silicone stents in the management of benign tracheobronchial stenoses. Tolerance and early results in 63 patients. Chest 1996; 109: 626-629.

Whittaker DK. Mechanisms of tissue destruction following cryosurgery. Ann R Coll Surg Engl 1984; 66: 313-318. Crit Care Med 1999; 160: 672-677.

Ramon P-P, Brichet-Martin A, Fournier C. Place de la bronchologie interventionnelle dans la prise en charge des cancers bronchiques [Interventional bronchoscopy in the management of lung cancer]. Rev Mal Respir 2005; 22: 8S106-8S111.

Lemaire A, Burfeind WR, Toloza E, et al. Outcomes of tracheobronchial stents in patients with malignant airway disease. Ann Thorac Surg 2005; 80: 434-437.

Saad CP, Murthy S, Krizmanich G, et al. Self-expandable metallic airway stents and flexible bronchoscopy: long-term outcomes analysis. Chest 2003; 124: 1993-1999.

Lin S-M, Lin T-Y, Chou C-L, et al. Metallic stent and flexible bronchoscopy without fluoroscopy for acute respiratory failure. Eur Respir J 2008; 31: 1019-1023. long-term follow-up. Eur J Cardiothorac Surg 2010; 38: 198-202.

, Gamarra F, Pfeifer KJ, et al. Fiberoptic bronchoscopic balloon dilatation in malignant tracheobronchial disease: indications and results. Chest 2001; 120: 43-49. option for patients ineligible for surgical resection. Thorax 2007; 62: 391-395.

McCaughan JS, Hawley PC, Brown DG, et al. Effect of light dose on the photodynamic destruction of endobronchial tumors. Ann Thorac Surg 1992; 54: 705-711.

Moghissi K, Dixon K, Stringer M, et al. The place of bronchoscopic photodynamic therapy in advanced unresectable lung cancer: experience of 100 cases. Eur J Cardiothorac Surg 1999; 15: 1-6.

Maziak DE, Markman BR, MacKay JA, et al., Photodynamic therapy in nonsmall cell lung cancer: a systematic review. Ann Thorac Surg 2004; 77: 1484-1491.

Diaz-Jiménez JP, Martínez-Ballarín JE, Llunell A, et al. Efficacy and safety of photodynamic therapy versus Nd-YAG laser resection in NSCLC with airway obstruction. Eur Respir J 1999; 14: 800-805.

Minnich DJ, Bryant AS, Dooley A, et al. Photodynamic laser therapy for lesions in the airway. Ann Thorac Surg 2010; 89: 1744-1748.

Vincent RG, Dougherty TJ, Rao U, et al. Photoradiation therapy in advanced carcinoma of the trachea and bronchus. Chest 1984; 85: 29-33.

Smith SG, Bedwell J, MacRobert AJ, et al. Experimental studies to assess the potential of photodynamic therapy for the treatment of bronchial carcinomas. Thorax 1993; 48: 474-480. obstruction. Chest 1990; 97: 662-665.

Speiser BL, Spratling L. Remote afterloading brachytherapy for the local control of endobronchial carcinoma. Int J Radiat Oncol Biol Phys 1993; 25: 579-587.

Huber RM, Fischer R, Haŭtmann H, et al. Palliative endobronchial brachytherapy for central lung tumors. A prospective, randomized comparison of two fractionation schedules. Chest 1995; 107: 463-470.

Trédaniel J, Hennequin C, Zalcman G, et al. Prolonged survival after high-dose rate endobronchial radiation for malignant airway obstruction. Chest 1994; 105: 767-772.

Chella A, Ambrogi MC, Ribechini A, et al. Combined Nd-YAG laser/HDR brachytherapy versus Nd-YAG laser only in malignant central airway involvement: a prospective randomized study. Lung Cancer 2000; 27: 169-175.

Hennequin C, Bleichner O, Trédaniel J, et al. Long-term results of endobronchial brachytherapy: a curative treatment? Int J Radiat Oncol Biol Phys 2007; 67: 425-430.

Pérol M, Caliandro R, Pommier P, et al. Curative irradiation of limited endobronchial carcinomas with high-dose rate brachytherapy. Results of a pilot study. Chest 1997; 111: 1417-1423.

Lunn W, Garland R, Ashiku S, et al. Microdebrider bronchoscopy: a new tool for the interventional bronchoscopist. Ann Thorac Surg 2005; 80: 1485-1488.

Casal RF, Iribarren J, Eapen G, et al. Safety and effectiveness of microdebrider bronchoscopy for the management of central airway obstruction. Respirology 2013; 18: 1011-1015.

Kato H, Konaka C, Ono J, et al. Preoperative laser photodynamic therapy in combination with operation in lung cancer. J Thorac Cardiovasc Surg 1985; 90: 420-429.

Chhajed PN, Somandin S, Baty F, et al. Therapeutic bronchoscopy for malignant airway stenoses: choice of modality and survival. J Cancer Res Ther 2010; 6: 204-209.

Chhajed PN, Eberhardt R, Dienemann H, et al. Therapeutic bronchoscopy interventions before surgical resection of lung cancer. Ann Thorac Surg 2006; 81: 1839-1843.

Moghissi K, Dixon K, Hudson E, et al. Endoscopic laser therapy in malignant tracheobronchial obstruction using sequential Nd YAG laser and photodynamic therapy. Thorax 1997; 52: 281-283.

Allison R, Sibata C, Sarma K, et al. High-dose-rate brachytherapy in combination with stenting offers a rapid and statistically significant improvement in quality of life for patients with endobronchial recurrence. Cancer $J$ 2004; 10: 368-373.

Ledingham SJ, Goldstraw P. Diathermy resection and radioactive gold grains for palliation of obstruction due to recurrence of bronchial carcinoma after external irradiation. Thorax 1989; 44: 48-51.

Shea JM, Allen RP, Tharratt RS, et al. Survival of patients undergoing Nd:YAG laser therapy compared with Nd: YAG laser therapy and brachytherapy for malignant airway disease. Chest 1993; 103: 1028-1031.

Jeon K, Kim H, Yu C-M, et al. Rigid bronchoscopic intervention in patients with respiratory failure caused by malignant central airway obstruction. J Thorac Oncol 2006; 1: 319-323.

Morris CD, Budde JM, Godette KD, et al. Palliative management of malignant airway obstruction. Ann Thorac Surg 2002; 74: 1928-1932. 
Wahidi MM, Jain P, Jantz M, et al. American College of Chest Physicians consensus statement on the use of topica anesthesia, analgesia, and sedation during flexible bronchoscopy in adult patients. Chest 2011; 140: 1342-1350.

Biro P, Layer M, Becker HD, et al. Influence of airway-occluding instruments on airway pressure during jet ventilation for rigid bronchoscopy. Br J Anaesth 2000; 85: 462-465.

102 Herth F, Becker HD, LoCicero J 3rd, et al. Endobronchial ultrasound in therapeutic bronchoscopy. Eur Respir J 2002; 20: 118-121.

103 Miyazawa T, Miyazu Y, Iwamoto Y, et al. Stenting at the flow-limiting segment in tracheobronchial stenosis due to lung cancer. Am J Respir Crit Care Med 2004; 169: 1096-1102.

104 Guibert N, Mazieres J, Lepage B, et al. Prognostic factors associated with interventional bronchoscopy in lung cancer. Ann Thorac Surg 2014; 97: 253-259.

105 Ost DE, Ernst A, Grosu HB, et al. Therapeutic bronchoscopy for malignant central airway obstruction: success rates and impact on dyspnea and quality of life. Chest 2015; 147: 1282-1298.

106 Amjadi K, Voduc N, Cruysberghs Y, et al. Impact of interventional bronchoscopy on quality of life in malignant airway obstruction. Respiration 2008; 76: 421-428.

107 Oviatt PL, Stather DR, Michaud G, et al. Exercise capacity, lung function, and quality of life after interventional bronchoscopy. J Thorac Oncol 2011; 6: 38-42.

108 Murgu S, Langer S, Colt H. Bronchoscopic intervention obviates the need for continued mechanical ventilation in patients with airway obstruction and respiratory failure from inoperable non-small-cell lung cancer. Respiration 2012; 84: 55-61.

109 Sayar A, Solak O, Metin M, et al. Carinal resection and reconstruction for respiratory tumors using Miyamoto's technique. Gen Thorac Cardiovasc Surg 2012; 60: 90-96.

110 Slawson RG, Scott RM. Radiation therapy in bronchogenic carcinoma. Radiology 1979; 132: $175-176$.

111 Eichenhorn MS, Kvale PA, Miks VM, et al. Initial combination therapy with YAG laser photoresection and irradiation for inoperable non-small cell carcinoma of the lung. A preliminary report. Chest 1986; 89: $782-785$.

112 Lam S, Kostashuk EC, Coy EP, et al. A randomized comparative study of the safety and efficacy of photodynamic therapy using Photofrin II combined with palliative radiotherapy versus palliative radiotherapy alone in patients with inoperable obstructive non-small cell bronchogenic carcinoma. Photochem Photobiol 1987; 46: 893-897.

113 Witt C, Dinges S, Schmidt B, et al. Temporary tracheobronchial stenting in malignant stenoses. Eur J Cancer 1997; 33: 204-208.

114 Rochet N, Hauswald H, Schmaus M, et al. Safety and efficacy of thoracic external beam radiotherapy after airway stenting in malignant airway obstruction. Int J Radiat Oncol Biol Phys 2012; 83: e129-e135.

115 Sutedja G, van Kralingen K, Schramel FM, et al. Fibreoptic bronchoscopic electrosurgery under local anaesthesia for rapid palliation in patients with central airway malignancies: a preliminary report. Thorax 1994; 49: 1243-1246.

116 De Ruysscher D, Nestle U, Jeraj R, et al. PET scans in radiotherapy planning of lung cancer. Lung Cancer 2012; 75: 141-145.

117 Guckenberger M, Wilbert J, Richter A, et al. Potential of adaptive radiotherapy to escalate the radiation dose in combined radiochemotherapy for locally advanced non-small cell lung cancer. Int J Radiat Oncol Biol Phys 2011; 79: 901-908.

118 Jiang Z-Q, Yang K, Komaki R, et al. Long-term clinical outcome of intensity-modulated radiotherapy for inoperable non-small cell lung cancer: the MD Anderson experience. Int J Radiat Oncol Biol Phys 2012; 83: $332-339$.

119 Homasson JP, Pecking A, Roden S, et al. Tumor fixation of bleomycin labeled with 57 cobalt before and after cryotherapy of bronchial carcinoma. Cryobiology 1992; 29: 543-548. 